\title{
Asbestos's Animacy; or, Salamander Cotton
}

Arthur Rose (University of Exeter)

As new technologies emerge, they demand that people adjust to reinscriptions of the ordinary. Some cope with these changes by ascribing an animacy or liveliness to these technologies. In this respect, they solicit a reappraisal of matter's agency, as examined by Actor-Network Theory, New Materialism, Object-Oriented Ontology, Thing Theory, and, of course, New Animism. This essay explores the question of animate matter by focusing on the mineral fibre, asbestos. In particular, it considers how asbestos acquires a liveliness in the thinking of those affected by it, as they process the all too real threat it poses to life. This acquisition occurs through a process of what I describe as interanimation, whereby the substance's animacy emerges from, and in dialogue with, its relation with human observers. To show how this develops through a long history of human-asbestos interactions, the essay recalls a close, if erroneous, association between asbestos and the mythical salamander, from Classical and Medieval Natural Histories to the poetry of Marianne Moore, Yves Bonnefoy, and Octavio Paz. By reanimating asbestos through the analogy of the salamander, I demonstrate how linguistic interanimation works: a two way process that depends on both human subjectivity and the animating power of discourse.

In a much-quoted paragraph near the beginning of "The Storyteller" (1936), Walter Benjamin reminds his readers of the radical shift in human experience that took place for the generation that lived through the First World War:

A generation that had gone to school on a horse-drawn streetcar now stood under the open sky in a countryside in which nothing remained unchanged but the clouds, and beneath these clouds, in a field of force of destructive torrents and explosions, was the tiny, fragile human body. ${ }^{1}$

Already vulnerable to more direct "destructive torrents and explosions," Benjamin's "tiny, fragile human body" also contends with a world made increasingly incomprehensible by accelerated technological innovation. Invoking this vulnerability in a larger discussion of Benjamin's work in relation to aesthetics, anaesthetics and technology, Susan Buck-Morss observes that technology, even as it intensifies the vulnerability of Benjamin's "body," "as a tool and a weapon extends human power $[\ldots]$ and thereby produces a counter-need, to use 
technology as a protective shield against the 'colder order' that it creates." "2 The cost of both power and shield, Buck-Morss argues, is anaesthetic, "as the synaesthetic system is marshalled to parry technological stimuli in order to protect both the body from the trauma of the accident and the psyche from the trauma of perceptual shock." (18) The result is numbness, deadened senses, repressed memory. Against this neurasthenia, Benjamin presents the following task for art, "to undo the alienation of the corporeal sensorium, to restore the instinctual power of the human bodily senses for the sake of humanity's self-preservation, and to do this, not by avoiding the new technologies, but by passing through them." (5)

In the essay that follows, I consider how such a project of undoing, restoration and passing through might apply to asbestos, a product that, from about seventy years before the publication of "The Storyteller," gained popularity as a protection against the more deleterious effects of mechanical production. A fire-resistant fibrous mineral once widely used in the insulation of buildings, asbestos's introduction into machinofactured capitalism in the late $19^{\text {th }}$ Century can be understood as a response to Buck-Morss's “counter-need", as a protection against fire. Even though it is a naturally occurring fibre, the processes by which asbestos is transformed by human labour to meet this counter-need effectively turned it into a technology.

Asbestos is now known chiefly for the diseases it causes: asbestosis, mesothelioma, pleural plaques and lung cancer. Like Benjamin's "tiny, fragile human body," the person faced with asbestos-related diseases must contend with a danger whose distortions of scale make it incomprehensible. Mesothelioma can take up to fifty years to manifest after the slightest of exposures. Asbestosis is the cumulative, and irreversible, scarring of lungs, after innumerable 
lacerations by fibres. Originally installed to protect the body from accidents and the mind from fears about these accidents, asbestos now invokes its own field of "destructive torrents and explosions" that extends spatially, across the built environment, and temporally, back into a past riven by accidental and unknown exposures.

For Benjamin, projects of undoing, restoration and passing through demand an "attentiveness" to "all living creatures [alle Kreatur]," which he finds exemplified in the work of Franz Kafka and Nikolai Leskov. ${ }^{3}$ This attentiveness to the creature or infra-human, argues Beatrice Hanssen, has an "ethico-theological dimension": it seeks "to reach down to a more originary level of ethical responsibility, one that antedated the destruction of experience." (157) Leskov, the eponymous “storyteller" of Benjamin's essay, achieves this attentiveness "the lower [he] descends on the scale of created things." In the story, "The Alexandrite," which "deals with a semiprecious stone, the chrysoberyl," Leskov reached " "the deepest layer of the creaturely' and expressed the voice of the nameless narrator, nature." (158) “The mineral," writes Benjamin, "is the lowest stratum of created things. For the storyteller, however, it is directly joined to the highest. To him it is granted to see in this chrysoberyl a natural prophecy of petrified, lifeless nature concerning the historical world in which he himself lives." Or, in Hanssen's gloss, "lending his ear to the chrysoberyl, Wenzel descended back in time, to a more original state of nature — before it was named and overnamed [...] by human language." (158) If Wenzel lends his ear to the chrysoberyl, this artistic observation is reliant on "a certain accord of the soul, the eye and the hand of someone who was born to perceive them and evoke them in his own inner self." The chrysoberyl is not animate a priori, but becomes animated through an intersubjective relation with its craftsman. Although neither Benjamin nor Hanssen make this point, it is the stone as technology, rather than as mineral, that permits this process of interanimation. 
To restore an instinctive power to asbestos as it appears in the built environment (i.e. as a technology), there is a subtle, but significant, effort by those exposed to it, their carers and their chroniclers to grant it an agency or an animacy. Apparently a thingly agency, as presented variously by Actor-Network Theory, New Materialism, Object-Oriented Ontology, Thing Theory and Vibrant Matter, this attention nevertheless carries an ethico-theological demand that resists the posthumanism explicit in these fields. The impetus behind ascribing asbestos an agency is a therapeutic attempt to salvage the subject from the technology's disorienting effects. When those affected by asbestos externalize its agency-casting it as a "resistentialism" inherent in the substance, or what Friedrich Theodor Vischer referred to as "Die Tücke des Objekts [the malice of objects]"- they are warding off this disorientation. ${ }^{4}$ Both the attempt to redeem the subject and the attribution of spiteful behaviour to the object (a personification, if not an anthropomorphization) contradict the explicitly desubjectifying aims of the "actor network" or "vital materiality." These contradictions demand a hermeneutic that can theorize the gesture as more than palliative and delusional whereby we might "lend our ears to" asbestos and see in it "a natural prophecy of petrified, lifeless nature concerning the historical world," while recognizing the shaping force of capitalism in this animacy.

It is not enough simply to identify the reanimation of the chrysoberyl or the ascription of malice to asbestos as aesthetic acts that supply "the artistic gratification of a sense perception that has been changed by technology." ${ }^{5}$ To celebrate their animacy without reflecting on their relation to capitalist cycles of extraction, production, consumption and waste flirts with a problem that Benjamin identifies with Fascism in the Epilogue to "The Work of Art in the 
Age of Mechanical Reproduction." "Fascism," writes Benjamin, "attempts to organize the newly created proletarian masses without affecting the property structure $[\ldots]$ giving these masses not their right, but instead the chance to express themselves." (241) This expression is manifested in the "introduction of aesthetics into political life" and, eventually, in war, which allows Capital to mobilize the technological resources of industry while preserving property relations. (241) After all, Capital itself uses the animation of objects to grant an expression that supports property rights, in a process that may be traced back to "the fetishism of commodities" and Marx's turning tables. ${ }^{6}$ If animated objects may help to support a denuded subject, this support must be qualified by the risk such objects pose: they may simply rehabilitate a history of capitalist animacy.

The argument presented above provides a pendant to this essay. First, the historical conditions that introduced asbestos into the built environment demand a project of restoration, undoing and passing through to innervate the numbed human subject. Second, this project might be realized in an attention to asbestos that, if not animist in belief, at least mimics animism in its formal attribution of agency to matter. Third, this attention remains risky, insofar as its aesthetics overlap similar projects that support the same capitalist conditions they aim to supplant. To attenuate the risks, we might invest our attention in an animacy whose reliance on magical thinking is both useful and self-evidently false. Without dismissing the need to enchant objects, we need to remain alert to enchantment's dangers. To illustrate how this "aware animacy" might work, I revive asbestos's historical affinity with the salamander. Through the "natural history" of asbestos's relation to the salamander, I offer a longer tradition in which contemporary accounts of asbestos's animacy may be fitted, and thereby justified, in tension with their appropriation by capitalism's magical discourses. 
The essay unfolds in four stages. First, I turn to three examples that illustrate a need to talk about asbestos's agency on the part of those exposed to it, those who care for the exposed and those who record the history of its industrial exploitation. Ascribing "a malice of objects" to asbestos has a therapeutic function, wherein the coherence of the psyche is salvaged by externalizing the numb incomprehension that asbestos disease produces and attributing to it an agency or animacy. To accommodate this coping strategy, I suggest a mode of attention focused on its linguistic animacy. Second, I consider how other scholars, mainly writing in the tradition of New Materialism, have found alternative means to grant asbestos direct agency, through its entanglements or the transcorporeality of its effects. However, this work comes into conflict with the wider, desubjectifying aim of New Materialism, precisely when it attempts to negotiate the therapeutic aims outlined above. In relying on the ethical observation of asbestos as an instance of Rob Nixon's "slow violence," these studies raise an obvious tension between intra-actions of matter and Nixon's aim to deliver "an environmentalism of the poor." Moreover, they miss a longer history wherein Capitalism, too, has used asbestos's agency to sell its products. Hence my preference for linguistic animacy. Third, I employ this linguistic animacy to "bring back to life," or reanimate, the tradition of thinking about asbestos as a product of salamanders. Undoubtedly false, it is a story that endures for almost a thousand years as a myth that must be refuted. In this falsity, it models an attribution of animacy that, paradoxically, remains attentive both to asbestos's liveliness and to the fictionality of that liveliness. Reviving this history, as it passes from "The Letter of Presbyter John" (ca. 1165) to the salamander poems of Marianne Moore (1944), Yves Bonnefoy (1953) and Octavio Paz (1962), leads me to the final stage of this essay, where I conclude that, by passing through the analogy of the salamander, we can 
maintain a relation with asbestos's animacy, while avoiding the damaging aestheticization that Benjamin associates with myth.

I

My first example of asbestos's ongoing animism comes from a conversation I had on a train, while travelling from Newcastle to Durham in the United Kingdom, with someone who installs boilers. The brief discussion turned to my interest in asbestos. "Asbestos", my interlocutor remarked, "that's the stuff that comes alive inside you, right?" Boilermakers, it has long been recognized, are at particular risk from exposure to asbestos, which was often used to lag, or insulate, hot water tanks. ${ }^{7}$ As such, asbestos features in their standard Health and Safety training. And yet, my interlocutor did not reproduce the litany of medical terms that populate the guidance documents. Rather he imagined asbestos through the metaphor of becoming-alive.

This attributed animacy resonates with my second example, "Pleased to Meet You", a poem by Joanne Barnes, a mesothelioma support worker and co-founder of the Asbestos Awareness \& Support Cymru who lost her father to the disease in 2012. "Pleased to Meet You" imagines asbestos itself as the speaker, "I", who reforms itself as "blue", "brown" and "white" (colours that correspond to the three main commercial types of asbestos: crocidolite, amosite, and chrysotile). 8 "I" lies "dormant", "lurking" in homes and environments, awaiting the opportunity to "surprise" the listener, "you". Underpinning Its shifting form, then, we can identify a language that emphasises asbestos's latency: something is present but unacknowledged and unannounced. ${ }^{9}$ Beginning and ending with the opening lines of the Rolling Stones's “Sympathy for the Devil”-_"Pleased to meet you / Won't you guess my 
name?"- the poem implicates responses to asbestos in a theology, where the substance is "evil", causing "all kinds of chaos". The poem does not restrict this imaginative evil to an empirically acceptable target, like the industry, although it is mentioned. Rather, asbestos is understood to be doing something itself, on its own: "I separate my particles", "travel", "roam free", and "come home from work". The actions Barnes associates with asbestos grants it agency by apostrophising, or personifying, it.

My final example emerges in the play between the title and subtitle of Geoffrey Tweedale's seminal From Magic Mineral to Killer Dust: Turner \& Newall and the Asbestos Hazard. ${ }^{10}$ As the subtitle suggests, the book gives a corporate history of Turner \& Newall, the largest asbestos producer in the United Kingdom, and their failure to report the health effects of asbestos. The main title implies a more profound epistemic rupture, as understandings of the substance transformed over the twentieth century. Importantly, this rupture does not contrast "magic" with its antonym, which might imply an evacuation of the supernatural. Rather, its power takes on a darker aspect, as the more passive "magic" is replaced by "killer", emphasizing asbestos's capacity to kill. If anything, the capacity to take life affords the already magical substance even greater agency. For Tweedale to deliver his necessary, and factually true, message about Turner \& Newall's corporate malfeasance, however, he must transfer the agentive qualities of the dust, implied in the main title, to the corporation that facilitated its dissemination. The emphasis on asbestos's agentive power in Tweedale's main title is in productive tension with the corporate focus of the book's subtitle. This is no mere semantic gamesmanship: this transfer of linguistic agency plays an important, even vital, role in transferring legal liability from the thing that kills to the entity responsible for the thing that kills. 
The three examples find, in animist language, the means to channel their concerns about asbestos. The boilermaker's metaphor speaks to a casual awareness that the diseases asbestos causes might as easily be understood as the asbestos itself gaining a life within one's body. Barnes's poem apostrophises asbestos to show how this life expands out, beyond the body, to sites of exposure. Tweedale's title uses a similar expansion to transfer malice from the object to the organization. Asbestos's animus, the mode of its animacy, allows for a Manicheanism otherwise difficult to explain though either the impersonal language of accident and exposure used by corporations, or the causal language of corporate self-interest and greed used by its critics. The substance's animosity against its victims feels too personal, proximate or immediate to be routed through a language focused on the uncaring channels of global capital. As important as blaming the corporation is for the compensation process, ultimately it risks eliding feelings that the body has betrayed itself by housing the interloping material. By allowing the substance itself to participate as an actant, each example responds to an unspoken need to have substances themselves evince a hostility its victims already feel. That this need carries into other responses to asbestos is evident when one locates this animacy as a point of tension in histories of the substance's industrial use. Indeed, one can detect such a tension in the scholarship's failure to reconcile fully the historical unfolding of the asbestos catastrophe with the affective animation of the material in its cultural reception.

This affective animation depends on treating an inert matter as if it were alive. In other words, it relies upon a dialectical play between animation and inanimation. David Wills has shown how the distinction between animation and inanimation is more fraught than it first appears. Beginning with John Donne's understanding of inanimation as, paradoxically, that 
which "enlivens, animates, quickens, infuses life into", Wills finds in the word a challenge to think "what is inanimate in animation, documenting the extent to which the inanimate animates". 11 "The inanimate," postulates Wills, “does not simply fall away, vehicled by mechanism, into the category of nonlife but continues to operate as an uncanny force across the divide that supposedly protects and defines life" (6). Accordingly, we might understand asbestos as not so much animate as troubling the ground between life and non-life: an inert substance that mobilizes animacy. This critical reflexivity guards against that aestheticized animacy, whose dangers Benjamin identifies in Fascism. Finding a starting point for a trenchant deconstruction of the "physocentrism of the natural as prior to, opposed to, and distinguishable from the artificial" and a rejection of "the oppositional categories of mechanism and vitalism, and the presumed inertness of matter" in the mechanistic philosophy of Descartes (7), Wills elaborates a conceptual contradiction in animacy that mirrors Mel Y. Chen's observations on linguistic contradiction. Like Wills, I want to use an intellectual history of asbestos's ontological indeterminacy as the means to elucidate the epistemological problem of animacy.

While Caroline Rooney acknowledges that instances of animism may be found in "Western Literature", she also dismisses these 'remnants of animism' as "idiosyncratic, deracinated and sometimes symptomatic of an alienated consciousness". ${ }^{12}$ But the matter of asbestos would itself remain alienated, were we not to address its animacy. To reverse this tendency, then, we must resuscitate asbestos's animism, not least because it remains an ongoing concern of asbestos scholarship in Sino-European writings from the European Classical Period through the European Early Modern. When asbestos's animacy is no longer confined to its recent history, we can find instances of natural history that entangle asbestos with salamanders, and which, in turn, tells the story of asbestos that "interanimates" across hierarchies of animacy. ${ }^{13}$ 
The stakes of this endeavour are not merely semantic, as my three opening examples attest. For people who routinely work with asbestos, like my train companion, historians of the industry, like Tweedale, and the carers left behind, like Barnes, asbestos has some kind of life. To establish the forms this life might take, we might think of the animacy they attribute to it as a feature of the language they use.

Like lead paint or mercury, asbestos seems to fit into a special group of substances whose interactions with fleshy life yield toxic effects. Their material consequences are inflected by their complex interaction with a grammatical feature called animacy, an expression of the sentience or aliveness of a noun's referent. Mel Y Chen's Animacies considers how the biological implications of lead paint and mercury evoke a feral consideration of linguistic animacy, given the strongly political ways in which both substances have been mobilized in racialised and ableist discourses. Such toxicants, Chen argues, violate implicit hierarchies of animacy. These hierarchies operate grammatically and conceptually, to reinforce the sedimented expectations that manifest through implicit bias, structural inequality, and more explicit racism, sexism, classism, ableism, and phobias about sexuality and gender identity. Such hierarchies can be traced at least as far back as Aristotle's De Anima. For Aristotle, life may be differentiated by its capacity to grow and reproduce, to move and feel, and to think and to reflect (characteristics of, respectively, the vegetative soul possessed by all living entities, the sensitive soul possessed by all animals, and the rational soul possessed by human animals). Higher order beings share the animate qualities of lower order beings, while also having additional qualities of animacy that mark them as different. Stones, like asbestos, or metals, like lead or mercury, occupy the lowest order of animacy, being essentially inanimate. But this hierarchy is frequently violated, demonstrates Chen in her consideration 
of the racialisation of lead and mercury, and for reasons that evidence the ways in which animacy plays across divisions between the linguistic and extra-linguistic.

Linguistic animacy, according to Chen, "is the quality of liveliness, sentience, or humanness of a noun or noun phrase that has grammatical, often syntactical, consequences" (24). Following Bernard Cowrie and Mutsumi Yamamoto, Chen describes it as a conceptual distinction that appears to operate across a wide variety of languages. Animacy was first developed as a linguistic category by Michael Silverstein, to explain split behaviour in ergative languages. Where accusative languages tend to mark the object of transitive verbs (the "me", as opposed to the "I", which functions as subject in both transitive and intransitive sentences), ergative languages exhibit morphological equivalence between the subject of an intransitive verb and the object of a transitive verb, which means that the subject of a transitive verb receives case marking. However, sometimes ergative systems display a split, where either the subject of a transitive verb or its object may be marked. Silverstein deployed animacy as a conceptual category to explain this split: on the grounds of an implicit hierarchy, conceptually less animate subjects are more likely to receive special ergative markings, to offset the apparent incongruity of their acting as more animate (i.e. as subjects). More animate subjects, not needing additional scaffolding to support their implicit claim to liveliness, retain an unmarked (that is, dominant) case (25-26). If discussions of animacy have advanced, as Chen documents, there remains an implicit hierarchy that functions to reinforce sexist, racist, classist, and speciesist ideas. However, as Chen also demonstrates, the exceptions or "ambivalent grammaticalities" of linguistic animacy may also be mobilised to deconstruct conceptual hierarchies, precisely in the ways these exceptions parse interactions between linguistic systems and their extra-linguistic contexts. For, if linguists traditionally take these hierarchies to be conceptual organisations of "things with grammatical 
consequence, [Chen reads it] as naturally also an ontology of affect: animacy hierarchies are precisely about which things can or cannot affect—or be affected by—which other things within a specific scheme of possible action" (30).

The following clause, lifted from the UK's Health and Safety Executive's website illustrates asbestos's linguistic animacy: "Asbestos still kills around 5000 workers each year" ${ }^{14}$ To the casual reader, there is nothing linguistically striking about this sentence, even if its emotive impact is quite startling. We read of substances that 'kill' often enough. More striking is the number of workers: an upsettingly high incidence, and one that has not declined ('still'). Yet, even in its most conversational sense, the term 'kill' implies an agency that demands an animate subject. After all, this is not the passive voice, which would occlude the direct action, 'kills', and render its animacy ambivalent, such as 'workers are killed by asbestos'. The creation of a middle voice category for 'kill', whereby the action is latent in the agent, might resolve the linguistic problem created, but it doesn't address the nagging doubt that there is something in asbestos demanding the position of the agent.

Asbestos, then, like lead and mercury, operates as a substance with greater animacy than its place in the hierarchy ostensibly suggests. When lead and mercury function as toxicants, they violate implicit hierarchies where stones and metals are treated as either absolutely or relatively "dead" or "inanimate". Invoking larger racial or ableist contexts, like the Chinese "lead panic" in the United States or the controversial links between autism and the neurotoxicity of environmental mercury, Chen demonstrates how toxicants, with "a potency that can directly implicate the vulnerability of a living body", challenge us to rethink relations where "the animacy criteria of lifelines, subjectivity and humanness (where the human wins) 
come up short against mobility and sentience (where the toxicant wins)" (203). Chen's examples play across three main categories: words, animals and metals. As words develop animacy, they cause us to challenge the implicit hierarchies that subordinate animals to humans, and metals to animals. Chen's account troubles that standard division that often opens guessing games: is it an animal, vegetable or mineral? What makes asbestos a fascinating interlocutor for Chen's work is that, unlike mercury or lead, whose surprising animacy emerges through juxtaposing their effects on bodies and discourses with their fixed ontological status as metals, asbestos's animacy is "queered" when one recalls that its history has always been characterised by ontological indeterminacy.

II

The linguistic animacy I have identified could be articulated through the language of ActorNetwork Theory, New Materialism, Object Oriented Ontology, Thing Theory or Vibrant Matter. But the liveliness of asbestos, it seems to me, is best described as a process of interanimation that depends as much on human investment as any inherent quality of the stuff itself. In Nurit Bird-David's contested understanding, animism seeks to "know the world by focussing primarily on relatedness [whereby] the knowing grows from and is the knower's skills of maintaining relatedness with the known." 15 This emphasis on the human investment in matter relations ultimately defines theoretical debates about asbestos's liveliness, whatever the critic's explicit discursive allegiances. By way of example, we might consider three excellent analyses of asbestos through New Materialist/Vibrant Matter analytics that effectively fetch up with forms of animism. Serenella Iovino, Sasha Litvintseva and Enrico Cesaretti have each drawn on Karen Barad's New Materialism to describe the "slow violence" that asbestos exerts upon tiny, fragile human bodies: the violence Rob Nixon 
describes as occurring "gradually and out of sight, a violence of delayed destruction that is dispersed across time and space, an attritional violence that is typically not viewed as violence at all."16 (14) Connecting a cellular interaction of fibre and flesh to individual exposures and to the historical contamination of communities in Balangero and Casale Monferrato in Northern Italy and Asbestos in Quebec, they invoke, variously, Barad's work on "intra-actions," (Iovino), "haptics," (Litvintseva) and "entanglements" (Cesaretti). For Iovino, asbestos cancers form through "a weird sequence of intra-actions." (151) Litvintseva imagines asbestos as linked to bodies and their environments by way of touch: "The toxic hapticity of asbestos operates by breaching of the boundary that appears to separate the insides of our bodies from our outward environments." (171) Cesaretti observes how "substances — be they organic or inorganic, natural or artificial — mix, and human beings are always entangled with both other subjects and other objects." (130) And yet, as Litvintseva notes, it is difficult, when considering asbestos workers,

to distinguish [their toxic embodiment] from what could be thought of as a form of psychological toxic embodiment latent in the capitalist reconfiguration of the relations between human and environment: a psychological suspension that put profit and growth over health and survival. (161)

This difficulty may account for why Iovino, for instance, qualifies her use of intra-action by quoting Barad on the responsibility it creates for human subjects: "reality is sedimented out of particular practices that we have a role in shaping and through which we are shaped." (Barad 390). Or, why Cesaretti, even as he imagines the asbestos dust as effecting a form of Stacy Alaimo's "transcorporeality" in the "collective and coemerging stories of people, places, and things," insists that "only these entangled narratives are the "antidotes to the invisible' - able to cure and enlighten at the same time." (152) Litvintseva's comparative failure to address asbestos workers' interpolation into capitalism betrays the general 
uneasiness about the desire to theorize asbestos's material entanglements, on the one hand, and the need to concede the "agential cuts" made by human subjects, on the other, when bearing witness to Nixon's "environmentalism of the poor." In the psychological suspension Litvintseva identifies (or in Iovino's responsibility and Cesaretti's antidote), animacy emerges not as a denial of subjectivity or personhood but as the means of their salvage.

When addressing the brute realities of asbestos's effects on people, the most determinedly New Materialist of critics grant the human subject an enduring, if diminished, role. Even Jane Bennett, in celebrating thing-power or "the moment of independence (from subjectivity) possessed by things," argues that the elevated status of a "shared materiality of all things" will ultimately be "good for humans." ${ }^{17}$ Likewise, when Bruno Latour invokes asbestos as "the last object to be called modernist" in Politics of Nature, he may do so to differentiate it as a "matter of fact" from the recent emergence of "matters of concern," but he still concedes, overwhelmingly, the human agencies behind its rise and fall. ${ }^{18}$ Less interested in the substance itself that its significance for the recent history of science, Latour does not even consider it as a possible "actant" in these debates. Whatever the theoretical excitations between the various matter studies, practically they respond to asbestos in ways more congruent with New Animism. Accordingly, knowers, people, maintain relatedness with what they know of asbestos, finding some sort of solace in the operations of animacy, which offers a countervoice to their inculcation within capital's deanimated, depersonalised regimes.

Still, one needs to be cautious about simply exulting in this magical thinking. Theoretically exciting as it might be, animacy has also been used to promote the asbestos industry itself. Histories of the substance, produced or financed by the industry, often reflected on the role 
that magic played in its history. ${ }^{19}$ From 1919 , Turner \& Newall promoted its material with a Lady Asbestos, styled as Britannia, protecting the pillars of "Ship-Building”, "Engineering”, "Building" and "Electricity" from the devastating effects of fire. Between 1952 and 1954, Cape Asbestos began to use a logo that depicted three human shapes in a fire: a reference to Shadrach, Meshach, and Abednego in the Book of Daniel, who are preserved from harm by an angel after Nebuchadnezzar commits them to a furnace. Far from being simple oddities of advertising, these examples of capitalist mythography suggest a correlative, if cynical, attempt to corral asbestos's animacy into the project of selling more product.

The failure of New Materialism to subordinate human agency entirely to the more-thanhuman speaks to a continued ethical responsibility to respond to the conditions of this corporate animacy. The dissemination of asbestos throughout the built environment cannot simply be attributed to a direct agency or animacy; it became ubiquitous because the asbestos industry found profit in it. Any engagement with asbestos's liveliness is a fraught endeavour that cannot be separated from contexts of capital and empire. Ahistorical reflections on asbestos's animacy risk dissimulating, distorting, or otherwise obscuring the historical culpability of the industry. Further, both the industry and its insurers have an ongoing responsibility to compensate for this damage. And yet, as the Scottish novelist James Kelman wrote on behalf of the Clydeside Asbestos Action in Glasgow, "compensation is not justice". ${ }^{20}$ If, in Kelman's thinking, this is because compensation remains a necessary but inadequate means to account for the injustice of deliberate asbestos exposure, the phrase further suggests that there is some excess, or "not-all", that falls between the ledger book of compensation and the aspirations of justice. This residual incompleteness parallels that excess of liveliness presented when asbestos comes alive in us. But justice demands that this liveliness attenuate, if not resist, efforts to absorb it into processes of commodity fetishism. If 
knowledge depends, as Nurit-Bird argues, on a knower's skills at maintaining their relationship with the known, then perhaps our attention needs to shift from ascribing liveliness (a process of displacement all too easily rendered synonymous with enchanting commodities) to the vehicles (metaphors, analogies etc.) we use to articulate this liveliness. Accordingly, by passing through the history of an object, we may find such vehicles, whose development may have occurred quite independently from the object's status as a commodity. To develop such a history, I turn now to a longer history of asbestos's ontological uncertainty, a history that involves magical thinking and salamanders.

III

Asbestos historiography, as an institution, presents asbestos as ontologically indeterminant from the earlier natural histories to the exposés of industry critics and the defences by corporate apologists. Iterations about asbestos from Theophrastus onwards display a surprising fluidity as asbestos transitions from a stone to a plant or an animal product. Rachel Maines, for instance, suggests that "descriptions of it in the middle Ages, and even well into the early modern period have mythical quality that would do justice to Ripley's 'Believe It or Not." ${ }^{21}$ When the "origin story" has been replicated by these histories, it has tended to repeat that problem identified by J. Alfred Fisher as early as 1892-3:

Much has already been written on the subject of asbestos, but I have been astonished to notice the great similarity in descriptive articles which have appeared from time to time in newspapers - even including scientific and technical papers and magazines. The writers seem, with amusing unanimity, to refer to some old encyclopaedia, and reproduce, with various comments, certain hackneyed statements about the use of asbestos cloth by the ancients of Greece and Rome, who thousands of years ago, 
wrapped the bodies of their dead in this material, and who made dinner napkins of asbestos, cleansing them after use by throwing them into a fire, and then exhibiting them to their amazed guests. ${ }^{22}$

Clare Browne, who quotes Fisher, and Maines, who does not, have both presented histories that are more critically engaged with their sources than those targeted by Fischer's historiography. However, they are both still oriented towards the resolution of asbestos's indeterminacy. Maines's engagement with historical antecedents serves principally to refute historicist assumptions about the disease association in the classical texts. While activist scholarship asserts that asbestos diseases may be traced as far back as the Greek geographer Strabo, Maines demonstrates the claim has no basis (26). Fisher, whose aim is comparatively less political, contextualises late $17^{\text {th }}$ Century debates around asbestos's nature in the Royal Society of London. Nevertheless, she displays a lingering Whiggish tendency, when she imagines that earlier anxieties around asbestos's ontological indeterminacy were resolved by determinations that it was a mineral.

Instead of simply repeating this pattern of historical revelation, I suggest that efforts to resolve asbestos's indeterminacy might be understood as exercises in autoimmunity, whereby assertions about its nature could stand in for the anxious state of wonder that it provoked. This state of wonder is more readily identifiable in an earlier explanation for its nature: that asbestos was the product of the salamander. By rehearsing some of the thematic continuities about asbestos, from Greek Natural Histories into the European Medieval Period, I establish where these anxieties emerged. Finally, I turn to three poetic examples, written between the 1930s and the 1960s, to indicate the long afterlife of this mythography and its significance for European animist cosmology. 
As C. Browne has demonstrated, members of the RSL were debating asbestos classification in 1684 , as a matter of scientific conjecture and refutation. But there was already a strong tradition that sought to identify asbestos as a mineral by refuting other possible explanations. In his 1646 Pseudodoxia Epidemica [Vulgar Errors], Thomas Browne aimed to disprove the "common error" that associated asbestos with salamanders:

That a Salamander is able to live in flames, to endure and put out fire, is an assertion, not only of great antiquity, but confirmed by frequent, and not contemptible testimony [...] It hath been much promoted by Stories of incombustible napkins and textures which endure the fire, whose materials are called by the name of Salamanders wool [...] Nor is this Salamanders wooll desumed from any Animal, but a Mineral substance Metaphorically so called from this received opinion. ${ }^{23}$

Browne aimed to correct erroneous understandings about the salamander, rather than asbestos, which would be the focus of the textile explorations of the Royal Society. Nevertheless, in order to reappraise the mythology that had accumulated around the animal, from both "great antiquity" and "frequent, and not contemptible testimony", he turns to the asbestos association because it presents the salamander's flame-retardant qualities as correlative, and therefore potentially, co-extensive to the mineral's. Tellingly, he first iterates sources that speak of salamanders and then of asbestos, but, since the sources are frequently the same, the impression this leaves the reader is that these parallels reflect connections the source materials themselves did, or should have, made, which is by no means the case. If Browne's method primarily echoed the style of classical and medieval historiography (the taxonomy of sources), Marco Polo had already disputed the conjunction on the basis of 
claims to direct experience in his Livre des Merveilles du Monde (c. 1300), also known as The Travels of Marco Polo:

And you must know that in the same mountain there is a vein of the substance from which Salamander is made. For the real truth is that the Salamander is no beast, as they allege in our part of the world, but is a substance found in the earth; and I will tell you about it. $^{24}$

Both T. Browne and Marco Polo reference the common, and faulty, understanding that salamanders and asbestos are, somehow, folded together, whether the salamander produces asbestos (“desumed from any Animal”), or may be identified as asbestos itself, "as they allege". Both suggest that the asbestos/salamander relation does function "metaphorically", but that the metaphor has been misapprehended as an identification of the substance's true nature. So, while they avow the ontological indeterminacy that I will presently trace in earlier natural histories of asbestos, they also seek to dispute this indeterminacy by presenting the "real truth". Behind their claims about the asbestos/salamander relation, however, lies a more convoluted history of fake narratives in the medieval period than might first appear.

In the Natural Histories, asbestos is recognised to be a rather odd duck. Theophrastus's De Lapidus [On Stones] (ca. 300 BCE), asbestos is given as "a stone which was like rotten wood in appearance. Whenever oil was poured on it, it burnt, but when the oil had been used up, the stone stopped burning, as if it were itself unaffected". ${ }^{25}$ An earlier tradition in Chinese history had identified asbestos as a linen, including Lih Tsze (ca. 500 BCE). ${ }^{26}$ When Pliny the Elder similarly describes asbestos as a "live linen", he suggests that asbestos cloths (asbestinon) might be sewn from something constitutively different from the asbestos gemstones (amiantus) he mentions elsewhere. ${ }^{27}$ In Book 19, on flax, he describes it as a "plant [that] 
grows in the deserts and sun-scorched regions of India where no rain falls, the haunts of deadly snakes, and it is habituated to living in burning heat", while in Book 37, on gemstones, asbestos is described as coming from the mountains of Arcadia and being of a red colour. In Book 36, on stones, Pliny associates asbestos with magic: “Amiantus resembles alumen in appearance, and suffers no diminution from the action of fire. This substance effectually counteracts all noxious spells, those wrought by magicians in particular." The ontological difference Pliny marks between amiantus and asbestinon, which simply identifies "raw" asbestos and its "woven" state, initiates a false distinction between asbestos as mineral and asbestos as technology that, nonetheless, remains useful when trying to think about the human tendency to animate it. For it is in its guise as technology, rather than as a mineral per se, that asbestos comes to be intersubjectively animated.

The connotations with magic, parsed by Pliny in Book 36, would find its correlative in other traditions. Ko Hung, in 320 CE, named asbestos alongside gold and cinnabar as highly esteemed traditional Chinese medicines for "an eternal life". ${ }^{28}$ If, for Pliny and Ko Hung, asbestos had intrinsic powers of protection and preservation, when Augustine writes of asbestos, in Chapter 5, Book 21 of De Ciuitate Dei (The City of God), it is more useful for its associative significance: he uses it as an exemplar for his argument that God performs miracles, under the heading "That there are many things which reason cannot account for, and which are nevertheless true". ${ }^{29}$ For Augustine, "there is a stone found in Arcadia, and called asbestos, because once lit, it cannot be put out". Since marvels such as these cannot be explained by reason, it follows that reason's inability to explain God's miracles is not a sufficient basis to argue their inexistence. 
Augustine's “confusion”, as Maines calls it, that asbestos will burn forever once lit continues through the works of Isidore of Seville, Marbode of Rennes and Albertus Magnus, and on through the patristics, as Maines herself documents. Its origins, however, are less interesting to me than its context: Book 21 of De Ciuitate Dei aims to examine the fiery punishment that awaits inhabitants of the City of God's counterpart, the City of the Devil. If asbestos, a stone that burns, is possible, so too might the eventual punishment by fire. But, it must also be possible that bodies might survive indefinite immersion in fire. By way of evidence, Augustine refers to salamanders, three chapters earlier than his mention of asbestos. He refers to "springs of water so hot that no one can put his hand in it with impunity a species of worm is found, which not only lives there, but cannot live elsewhere" (404). These "salamanders", he continues in Chapter 4, provide sufficiently convincing examples that "everything which burns is not consumed" (406). Critically, Augustine does not relate salamanders to asbestos, even if their juxtaposition, through Book 21's theological argument about eternal flame, makes subsequent associations more understandable.

In Asbest in der Vormoderne, Jan Ulrich Büttner tracks the salamander/asbestos interface over the long Middle Ages. ${ }^{30}$ He demonstrates that the association is not, as T. Browne implies in his recitation of Theophrastus et al, foregrounded until the appearance of the Letter of Prester John (ca. 1165) and the consolidation of the Roman d'Alixandre by Alexandre of Paris (ca. 1180). From these two, apparently independent sources, traces of the association proliferate in both courtly poetry and natural history through the later $12^{\text {th }}$ and early $13^{\text {th }}$ centuries. This dual reception may be explained, Büttner notes, by the ambiguities surrounding the Letter, in particular. Written in the form of a communique between the Byzantine emperor, Manuel Comnenus, and a Christian priest-king ruling over a hitherto unknown kingdom in Central Asia, the Letter claimed to detail the many wonders of the 
kingdom. Its credence at the time was such that Pope Alexander III sent a response. The source of confusion about salamanders and asbestos may be found in this passage:

In one of our lands, hight Zone, are worms called in our tongue Salamanders. These worms can only live in fire, and they build cocoons like silk-worms, which are unwound by the ladies of our palace, and spun into cloth and dresses, which are worn by our Exaltedness. These dresses, in order to be cleaned and washed, are cast into flames... ${ }^{31}$

Here we find the prototype description, which, in conjunction with Pliny and Isidore, would work its way through the natural histories of Gervasius of Tilbury (ca. 1209-1214), Jacques de Vitrys (1220/21), Thomas von Cantimpré (1226), and Bartholomaeus Anglicus (1235). Marco Polo and T. Browne are writing against this tradition, and that of differentiating asbestos stone from asbestos cloth.

It seems fair criticism to note that animal products, like wool, are not lively, whether they come from sheep or salamanders. Here, the refutations of Marco Polo and T. Browne actually instantiate the liveliness they attempt to dispute. By returning asbestos to its mineral classification, they undermine the metaphoric protection that salamanders, in their mythical intransigence, afforded as magical explanations for the properties of the material. Marco Polo, for instance, speaks of the salamander being itself the material, while T. Browne reckons its incombustibility is "the more remarkable". Where associations with the salamander had the dubious benefit of elevating asbestos in an implicit animacy hierarchy, in turn, its affective claims became more reasonable, for being explained by magic. By denying this relationship and insisting on asbestos's minerality, the accounts of Marco Polo and T. Browne threaten this order, albeit without registering it as a threat, since they open up the 
question of asbestos's incombustibility without proffering an explanation for how it works, whether affective or empirical, beyond the marvellous.

The long conceptual history of asbestos and salamanders suggests the animacy tension is neither new nor isolated, even if responses (like those of Marco Polo and T. Browne) have sought to "deny, disallow, disavow, discredit" such animacy, leading to "a double disavowal: an anti-naturalism that seeks to deny that all human beings are a part of nature; and a certain hyper-materialism that seeks to deny the vitality or dynamism of matter". ${ }^{32}$ In light of this tendency, I want to turn to three poems that, in resuscitating the mythology of the salamander for the twentieth century, effectively initiate a process of "interanimating" asbestos: Marianne Moore's “His Shield” (1944), Yves Bonnefoy’s “Lieu de la salamander [Place of the Salamander]" (1953), and Octavio Paz's "Salamandra [Salamander]" (1962). ${ }^{33}$ When put in conversation with the natural histories mentioned above, these poems are also deliberately returning to animist modes of mythopoesis. But they do so either from within so-called "Western" traditions from the United States (Moore) or Europe (Bonnefoy), or from an interstitial point of communion between Western and Indigenous cosmologies (Paz). Their respective use of the salamander, and its historiographic mutations, can be itself one mode of recognising a material that remains ambiguous in its interanimation. So, while Moore makes substantial use of asbestos, Paz mentions it twice, and Bonnefoy not at all, their use of the salamander means their poems still operate as part of a constellation of animist asbestos poetry.

This constellation is clearest, being explicit, in Marianne Moore's "His Shield". The speaker imagines adopting the protective reflex of the hedgehog in the first strophe, only to dismiss 
this "pig-fur" in favour of wrapping "myself in salamander-skin, like Presbyter John". Explicitly invoking the Letter, discussed above, the speaker extends the protections of hedgehog to those of the mythical salamander. The protection it offers, "asbestos-eyed, asbestos-eared", is not simply to fire and water. For, as the poem develops, the presbyterturned-salamander also offers "a formula safer than / an armorer's", a "humility" (the eponymous "shield" of the poem) manifested in "the power of relinquishing / what one would keep". However protected by armour the speaker might be, Moore concludes, they should also "be / dull. Don't be envied or / armed with a measuring-rod".

Elsewhere I have suggested that Moore's reference to asbestos fits within a broader modernist tradition, whereby the substance stands in for a general immunity, or insulation, from touch. ${ }^{34}$ Indeed, "His Shield" has generally been read as an illustration of Moore's armoured poetics, at least as far back as Randall Jarrell's 1952 review, “Thoughts about Marianne Moore" (later republished as "Her Shield" in Poetry and the Age). ${ }^{35}$ But, as Sabine Sielke has argued, "the common notion that Moore's defensive discourse primarily serves to protect a self supposedly hidden beyond the textual surface misses the mark". ${ }^{36}$ Rather, the image serves to "construct a subject by protecting its body", the armour being, as Moore herself would write for Mary Austen's Everyman's Genius (1925), “impressively poetic. The moveable plates suggest the wearer; one is reminded of the armadillo and recalls the beauty of the ancient testudo [...] an armor in which beauty outweighs the thought of painful selfprotectiveness". ${ }^{37}$ Armour, for Moore, merges the subject with their appearance, an insight one "remembers" via animals that are coextensive with their armour, like the armadillo, the testudo, or, the animal that Moore concludes the passage with, the iguana. Jarrell may then have been ostensibly correct when he noted that "His Shield" no longer trusts in armour in the same way as Moore's earlier poems. However, he perhaps misses the ways in which 
Moore's creaturely analogues (her "animiles") were always designed to subvert straightforward interpretations of armour as protective of a hidden subject. Indeed, it seems that Moore's animals serve to reanimate innervated subjects, by granting their armour an animacy. Or, to put it in terms closer to those of Benjamin's, through an attentiveness to the supposedly inanimate, Moore presents us with an example of creaturely interanimation.

This may be generalized to the function of the animal analogy in Moore's larger oeuvre. Dancy Mason, taking issue with the tendency to read Moore's animiles as "animal collectibles" (Rieke), "self-portraits" (Bazin) or "postcards" (Jarrell), argues that "Moore's animiles use figurative prosthesis (foreign additions to the body through metaphors and similes) to hyperextend her animal depictions beyond contained definitions of the animal, just as a limb or joint can hyperextend beyond its normal limits". ${ }^{38}$ Rather than simple illustrations, Mason argues, Moore's animal similes present her with opportunities to extend her thinking through analogies that aren't constrained by natural morphologies. This is apparent in "His Shield" when the speaker's focus shifts from the hedgehog to the salamander. As in Augustine, Marco Polo or T. Browne, the salamander is considered as a natural wonder that extends examples of the creaturely beyond the limits of reason. Moreover, when the "I" (an unusual pronoun in Moore's later work), wraps themselves in salamander-skin like Presbyter John, they become "a lizard in the midst of flames", which in turn blurs into a "he", whose country recalls the descriptions of the apocryphal Letter. This metamorphosis is completed in the lines, "the inextinguishable / salamander styled himself but presbyter" (179). Sheathing the self in salamander skin effectively turns the I, like Presbyter John before, into a salamander, not through a process of actual transformation, but through the pressure the poem places on conventional syntax, a pressure we will see repeated in the salamanders of Bonnefoy and Paz. Using the animal is not, or not simply, an analogy in 
these cases. It fuses illustration to reality in a way that, like an animal's armouring, makes it impossible to separate image from the connection imagined.

In her contribution to Austen's Everyman's Genius, Moore turned to the image of animal armour to illuminate her explanation of the origins of a poem:

An attitude, physical or mental - a thought suggested by reading or in conversation recurs with insistence. A few words coincident with the initial suggestion, suggests other words. Upon scrutiny, these words seem to have distorted the concept. The effort to effect a unit - in this case a poem - is perhaps abandoned. If the original, propelling sentiment reasserts itself with sufficient liveliness, a truer progress almost invariably accompanies it. (339)

Moore's description of the poem, buoyed up by the liveliness of the concept and the appropriateness of the words, provides a fitting analogue to that given by Yves Bonnefoy in "La Poésie français et la principe d'identité". When he sees a salamander on the wall, he can "mentally separate this tiny life from the other data of the world and classify it, as the language of prose would, telling myself: 'A salamander,' then continue my walk, absentminded as ever". ${ }^{39}$ (Improbilite, 246-247). Rather than a mythopoetic beast, salamander, here, is a classification, a scientific refinement of a more generic lizard. Bonnefoy's response to the salamander illustrates a phenomenological process, whereby what is first apprehended as world is gradually distinguished, separated, through mental classification. But should "this reality [the world] come together again",

it is as if I had accepted, lived, that salamander, and henceforth, far from having to be explained by other aspects of reality, it is the salamander, present now as the gently beating heart of the earth, which becomes the origin of all that is $[\ldots]$ the salamander 
has revealed itself, becoming or rebecoming the salamander [...] in a pure act of existing in which its essence is seized and understood. ${ }^{40}$ (I 247-48)

Reasserting, to adopt Moore's term, the salamander "with sufficient liveliness" in this way reorients the world, as it is received, around the salamander, which becomes a point of "origin". For the observing poet, this reoriented origin impacts the unity of place as a continuity and a sufficiency (comparable to its stimmung or attunement): “[the salamander's] essence has spread into the essence of other beings, like the flow of an analogy by which I perceive everything in the continuity and sufficiency of a place, and in the transparency of unity." (248) Bonnefoy's salamander is, therefore, the correlative to Moore's iguana, mentioned at the end of her response to Austen, since both function to return the poet to a moment that seemed to be lost, whether through the agglutination of words (for Moore) or through the classifying impulse (for Bonnefoy). Both enliven the perceptive capacity of the observing subject, through "the flow of an analogy": the lizards spread their essence into other things not least because their association revivifies the meaning of "armour" or of "the unity of place" for poetic language. By subverting efforts to objectify the lizards and insisting on their surprising relations, both poets develop a context whereby the salamander's animacy might be translated to speak of asbestos's strange animacy, as originating in a process of interanimation.

As noted by scholars like John Naughton and Layla Roesler, Bonnefoy's essay provides a subsequent context for the Salamander poems in his 1953 collection, Du mouvement et de l'immobilité de Douve [On the Motion and Immobility of Douve] ${ }^{41}$ Although any one of these poems might serve our purpose, the poem that most obviously anticipates the later essay is "Lieu de la salamander [Place of the salamander]". ${ }^{42}$ Comprising an opening quintet, 
followed by three quatrains, the poem develops the image of "la salamander surprise [the startled salamander]" who "s'immobilise / Et feint la mort [freezes and feigns death]", from its physical place, "à mi-hauteur / Du mur, dans la clarté de nos fenêtres [halfway up / the wall, in the light of our windows]", to the force it exerts on the poet and other bodies: "Que j'aime qui s'accorde aux astres par l'inerte / Masse de tout son corps [How I love that which gives itself to the stars by the inert / Mass of its whole body]". The attention Bonnefoy's speaker gives to the salamander is returned in the pull it exerts with the inert mass of its body.

Bonnefoy's salamander is not, however, wholly subtracted from its mythical origins. For, if the alliterative endings of "surprise" and "s'immobilise" already anticipated the salamander's response as an astonishment (i.e. to be stunned), the poem goes on to parse this astonishment as a transition from consciousness to stone, as if through a fiery transfer of spirit: "Tel est le premier pas de la conscience dans les pierres, / Le mythe le plus pur, / Un grand feu traversé, qui est esprit [This is the first step of consciousness into stone, / The purest myth, / A great fire passed through, which is spirit]". As for Benjamin, the highest stratum of consciousness is traversed by returning to the lowest, the stone. Furthermore, the passage's Hegelian undertones refer back to the collection's epigraph, taken from Hegel's preface to Phenomenology of Spirit: “Mais la vie de l'esprit ne s'effraie point devant la mort et n'est pas celle qui s'en garde pure. Elle est la vie qui la supporte et se maintient en elle [But the life of the spirit is not the life that shrinks from death and keeps itself untouched by devastation. It is the life that endures it and maintains itself in it]". Whatever else we might say of the myth "le plus pur", by invoking stones, purity and fire, the poem implies a connection back to "amiante", French for asbestos, derived from the Greek "amiantos" meaning "undefiled". But such stones are themselves reanimated by the salamander, which is, according to Bonnefoy, "allégorie / De tout ce qui est pur [allegory / of all that is pure]", since even if "Son regard 
n'était qu'une pierre, / Mais je voyais son cœur battre éternel [Its gaze was merely a stone, / But I could see its heart beating eternal]’. The stony gaze is reanimated by an eternally beating heart, maintained by the devastation that surrounds it.

While Bonnefoy's salamander seems to bear but little resemblance to Moore's, or those of the Classical, Medieval and Early Modern Periods, both the poem and the poetics clearly use the salamander, as it flits from reptile to stone to spirit, to think about their own powers of linguistic animation, through metaphor and analogy. Again, this is facilitated through a syntax that violates implicit hierarchies, which might shy away from "first steps from conscience into stones". Oriented, however, as Bonnefoy and Moore are, to systems of thinking that conflate Western with Universal, their salamanders remain products of naïve orientalism, albeit an orientalism shared by key Chinese thinkers. While the extreme particularity of the linguistic appears to run beneath the ethnographic while the generality of the philosophical rises above it, both risk covert claims to essentialism and universality. To address this concern more directly in my final example, I turn to Octavio Paz's "Salamandra [Salamander]".

As with other instances of Paz's appropriation of Indigenous identity, "Salamandra" engagement with Indigenous cosmology is not unproblematic. Writing of Paz's representations of Indigenous persons, Analisa Taylor remarks that it "exemplifies an indigenista literary sensibility. Because indigenous peoples speak languages that are incomprehensible to the author [...] they are bestowed with an eloquent silence". ${ }^{43}$ Nevertheless, "Salamandra" does offer a response to the salamander that perhaps offers a less Eurocentric approach than its antecedents, less because it includes Indigenous cosmology 
(which, Taylor suggests, is part of the problem) than because it effaces structural markers of preference or hierarchy. Critics like John Fein note of Salamandra that it departed from Paz's earlier, more structurally determinist works. Were the reader to be generous, Paz's inclusion of Indigenous cosmology in Salamandra might be taken not so much as appropriation, as a recognition of the salamander's place in Mexico's longer history. John Fein notes that in the collection, Paz abandoned the relationship between structure and theme that overdetermined works like El laberinto de la soledad [The Labyrinth of Solitude] (1950/1961), in favour of themes that developed through the intensification of the poetic subject. ${ }^{44}$ Fein suggests that this intensification, and its concomitant "destructuring", is managed by omitting punctuation and making greater use of columnar typography, both of which are evident in "Salamandra" (42). The poem reads like an exercise in paratactic enumeration: each feature of the salamander presented as a discrete conceptual unit that evokes a particular understanding of the salamander. The overall effect of the juxtaposition is a salamander that metamorphoses in different natural, cultural or political milieus.

All but one of the poem's strophes begin by invoking the "Salamandra", going on to develop a different abstract, historical, physical or theological association. These assays reflect the diverse ways in which the salamander has been conceived in history, as well as the immense heterogeneity of salamanders that exist in the natural world (there are some 655 living species). By refusing to differentiate those salamanders evidenced by empirical research from those that appear in earlier natural histories and religious texts, Paz produces a composite salamander, bound to processes both of becoming and of decay and transience. Two strophes are, in particular, useful for our argument, since they invoke, respectively, the European myth of the salamander (complete with asbestos) and the religious appearance of the axolotl in Aztec cosmology. 
In verse 2, the salamander is recalled as "nombre antiguo del fuego / y antídoto antiguo contra el fuego [ancient name of fire / and ancient antidote to fire]". It both names the fire and immunizes the subject from it, represented in the ambiguous next line, "y desollada planta sobre brasas [flayed sole of the foot over hot coals]". If we endorse Denise Levertov's translation, the flayed foot might be an obscure allusion to Plutarch's account of Pyrrhus, whose toe survives his funeral pyre (mentioned by both Pliny and Thomas Browne). However, the "desollada planta" may also be translated as a flayed plant, thereby reprising the confusion between plants and stones in Pliny's Natural History. This confusion is authorised by Paz because the next and final line of the strophe is "amianto amante amianto", which Levertov gives as "amianthus amante amianthus", but which retains both its strangeness and its clear relation to my argument if translated as "asbestos lover asbestos". Levertov clearly aims to maintain the repetition in each word's onset “am”, but Paz's decision to enclose his "lover" in two "asbestoses" is perhaps more interesting when we follow the "ama" of "amante" to the poem's repetition of "Salamandra", to the various "llamas [flames]" through which the salamander passes, including those at the end, when the poet suggests that if the salamander carves herself in flames, this will only result in her setting fire to this "monumento [monument]".

The confusion of these contingent transformations are resolved in the thirteenth strophe of the poem, the longest and the only one not to begin with a salamander invocation. It details the story of the Aztec God, Xólotl, “el dos-seres [the twin-being]”, who, like the axolotl he resembles, metamorphosises to escape death. ${ }^{45}$ When the sun stops, it is expected that Xólotl will eat himself, but he refuses, transforming instead into maize, then agave and finally an 
axolotl. In each form he is found, and, finally, he is killed, enabling the sun to move once more. Xólotl, Paz recalls, is a psychopomp, guiding the dead to their final destination. Like most psychopomps, this means he navigates between worlds and between hierarchies of animacy. But he is also tied to natural forms of metamorphosis through the axolotl, which is a neotenic salamander. Although neotenic animals generally reach adulthood without undergoing metamorphosis, axolotls have been known to complete metamorphosis if they ingest enough iodine, sometimes achieved through cannibalism. Thus the injunction that Xólotl should eat himself might also be understood as a charge to complete metamorphosis, or the process of becoming, that Xólotl abjures in favour of a Protean myriad of forms. Xólotl's abjuration prolongs a momentary halt to time in which the God makes free use of his ability to transition across apparently inviolable hierarchies of animacy. But the halt must necessarily be transitory. Like the autopoesis of the salamander's carving, which, being made of flames, consumes itself as monument, the fleeing God must eventually be found and killed to restart time and conclude its metamorphosis.

If this reading of Paz's poem is necessarily partial, it also appears to have drifted our discussion off course. For, while asbestos describes a substance that is, like Xólotl, polymorphous, that, like Xólotl, move in temporalities out of synch with those readily apprehended by the human, Paz's subordination of the asbestos myth to merely one of the salamander's many incarnations suggest the marginality of the substance to any but the more superficial discussions of the creature. This conclusion is only compounded by Bonnefoy, who does not mention it all. Even Moore, who gives it more attention than the others, develops her argument as a response to Prester John. In following their explorations of the mythos of the salamander, then, my readings of Moore, Bonnefoy and Paz have carried us quite a distance away from asbestos itself. Nevertheless, by what Bonnefoy might call "the 
flow of an analogy", I have hopefully demonstrated what I simply seemed to propose: the salamander analogy serves to maintain a relationship between me (or, hopefully, you, the reader) and the asbestos that is my object.

One of the problems I identified at the opening of this essay was the internal contradiction between identifying asbestos's agency and its agents when considering the victims of asbestos related diseases. To reassert the substance's animacy, I found a "solution" in its ontological indeterminacy, realised philosophically, through the play between animation and inanimation (Wills), and linguistically, through the play across implicit hierarchies of animacy (Chen). Like Wenzel in Leskov's tale, we must "listen" to asbestos to find "a natural prophecy of petrified, lifeless nature." In the subversive animacy ascribed to asbestos by its victims, their carers and their chroniclers, we can find just such a process of attentiveness, wherein granting a life to asbestos, paradoxically, brings them closer to the world, innervates them. But, applying this solution directly produces a problem: that such reflection only distances our treatment of the substance from its position as an everyday object, where it sits, latent but inert. Moreover, when responding to asbestos, efforts to grant it agency must be balanced against the workings of capital, which, in its exploitation of asbestos, whether through mining, production, commercial use or disposal, or through the legacy of this exploitation, remains wholly responsible for its hazardous disposition. Much as Benjamin cautioned against the casual aestheticization of politics without challenging existing property relations, asbestos's animacy must point to a general failure of understanding without excusing capital for allowing this failure to manifest in asbestos's deadly liveliness. Rather than assert a quasi-mystical animacy in the substance itself, the salamander emerges as conduit for this animacy, an illustration that also operates as its necessary mediation. Precisely because the salamander is not asbestos, but is, in its natural history, wholly 
imbricated with it, the salamander can be understood to be the necessary analogue for

asbestos's animacy, a necessary fiction that allows us to listen to the stone, while

acknowledging that it does not speak.

\footnotetext{
${ }^{1}$ Walter Benjamin, Illuminations, translated by Harry Zohn, New York, Schocken Books, 2007, p. 84.

2 Susan Buck-Morss, “Aesthetics and Anaesthetics: Walter Benjamin's Artwork Essay Reconsidered”, October 62 (1992), 3-41, 33.

${ }^{3}$ Beatrice Hanssen, Walter Benjamin's Other History: Of Stones, Animals, Human Beings and Angels, Berkeley, University of California Press (2000), 152.

${ }^{4}$ Friedrich Theodor Vischer, Auch Einer, Stuttgart, Deutsche Verlags-Anstalt, 1900, 24.

${ }^{5}$ Walter Benjamin, "The Work of Art in the Age of Mechanical Reproduction”, Illuminations, 242.

${ }^{6}$ Karl Marx, Capital Vol. 1, London, Penguin, 1990, 163-4.

${ }^{7}$ R. Y. Demers, A. V. Neale, A.V., Robins, T. and Herman, S.C. (1990), Asbestos-related pulmonary disease in boilermakers. Am. J. Ind. Med., 17: 327-339.

${ }^{8}$ Joanne Barnes, "Pleased to meet you", Asbestos Awareness and Support Cymru, Accessed 24 September 2019: http://a-a-s-c.org.uk/wp-content/uploads/2012/01/pleased-to-meet-you.pdf

${ }^{9}$ Hans Ulrich Gumbrecht, "How (if at all) can we encounter what remains latent in texts?" Partial Answers, 7, 1 (2009), 87-96, 88 .

${ }^{10}$ Geoffrey Tweedale, From Magic Mineral to Killer Dust: Turner \& Newall and the Asbestos Hazard, Oxford, Oxford University Press, 2000.

${ }^{11}$ David Wills, Inanimation, Minneapolis, University of Minnesota Press, 2016, ix; x.

${ }^{12}$ Caroline Rooney, African Literature, Animism and Politics, New York and London, Routledge, 2000, 13.

${ }^{13}$ Mel Y. Chen, Animacies: Biopolitics, Racial Mattering, and Queer Affect, Durham, Duke University Press, 2012,30 .

14 "Why is asbestos dangerous?", Health and Safety Executive. Accessed 24 September 2019:

http://www.hse.gov.uk/asbestos/dangerous.htm

${ }^{15}$ Nurit Bird-David, “'Animism' Revisited: Personhood, Environment, and Relational Epistemology”, Current Anthropology 40, S1 (February, 1999): S67-S91, S69.

${ }^{16}$ Serenella Iovino, Ecocriticism and Italy: Ecology, Resistance, and Liberation, London, Bloomsbury, 2016;

Sascha Litvintseva, “Asbestos: Inside and Outside, Toxic and Haptic”, Environmental Humanities 11, 1 (2019), 152-173; Enrico Cesaretti, Elemental Narratives: Reading Environmental Entanglements in Modern Italy, University Park, Penn State University Press, 2020; Karen Barad, Meeting the Universe Halfway: Quantum Physics and the Entanglement of Matter and Meaning, Durham, Duke University Press, 2007. Rob Nixon, Slow Violence and the Environmentalism of the Poor, Cambridge, Harvard University Press, 2011, 14.

17 Jane Bennett, Vibrant Matter: A Political Ecology of Things, Durham, Duke University Press, 2010, 3; 13.

${ }^{18}$ Bruno Latour, Politics of Nature: How to Bring the Sciences into Democracy, translated by Catherine Porter, Cambridge, Harvard University Press, 2004.

${ }^{19}$ See, for instance, Robert H. Jones, Asbestos, Its Production and Use: With Some Account of the Asbestos Mines of Canada, London, C. Lockwood and son, 1888; A. Leonard Summers, Asbestos and the asbestos industry: the world's most wonderful mineral and other fireproof material, London, Pitman, 1920 and Oliver Bowles, Asbestos: Silk of the Mineral Kingdom, New York, The Ruberoid Co., 1946.

${ }^{20}$ James Kelman, "Justice is not Money”, in J. Kelman, And the Judges Said... Essays, London, Vintage, 2003.

${ }^{21}$ Rachel Maines, Asbestos and Fire: Technological Tradeoffs and the Body at Risk, Rutgers, Rutgers University Press, 2005, 24.

22 J. Alfred Fischer, "The Mining, Manufacture and Uses of Asbestos", Transactions of the Institute of Marine Engineers (1892-93), qtd. In Clare Browne, "Salamander's Wool: The Historical Evidence for Textiles Woven with Asbestos Fibre", Textile History, 34, 1 (2003), 64-73, 64.

${ }^{23}$ Thomas Browne, Pseudodoxia Epidemica, Book 3, Chapter 14, 1646/1672. See also the refutation of Browne's salamander discussion in Alexander Ross, Arcana Microcosmoi, Book 2, Chapter 1, 1652. Both texts may be found at Sir Thomas Browne, Accessed 24 September 2019: http://penelope.uchicago.edu/index.html. ${ }^{24}$ Marco Polo, The Travels of Marco Polo, translated by Henry Yule, edited by Henri Cordier, London, John Murray, 1920, Volume 1, Chapter 42, 595.

25 Theophrastus, On Stones, introduction, translation and commentary by Earle R. Caley and John F. C.

Richards, Columbus, University of Ohio Press, 1957, 48; 87. According to N.F. Moore, in Ancient Minerology,
} 
New York, 1857, this passage alludes to asbestos. However, Caley and Richards dispute this, stating it more likely that Theophrastus refers to brown fibrous lignite (88). Since my own interest is in asbestos's disputed nature, this dispute emphasises the confusions around subsequent efforts to identify asbestos in ancient sources. ${ }^{26}$ For a survey of Chinese sources, see Berthold Laufer, "Asbestos and Salamander, an Essay in Chinese and Hellenistic Folk-Lore”, T'oung Pao, 16, 3 (1915), 299-373.

${ }^{27}$ Pliny, Natural History, translated by H. Rackham, W.H.S. Jones and D.E. Eichholz. Wikisource. Accessed 24 September 2019: https://en.wikisource.org/wiki/Natural History (Rackham, Jones, \%26 Eichholz)

${ }^{28}$ Ko Hung, Qtd in Maines, Asbestos and Fire, 26.

${ }^{29}$ Aurelius Augustine, The City of God, Volumes I \& II, edited and translated by Marcus Dods, Edinburgh, T\&T Clark, 1871, 407.

${ }^{30}$ Jan Ulrich Büttner, Asbest in der Vormoderne: Vom Mythos zur Wissenschaft, Münster, Waxmann Verlag $\mathrm{GmbH}, 2004$.

31 "Letter of Prester John", Selections from the Hengwrt Mss. Preserved in the Peniarth Library, edited and translated by Robert Williams, London, Thomas Richards, 1892. Reproduced at Celtic Literature Collective, Accessed 24 September 2019: http://www.maryjones.us/ctexts/presterjohn.html

${ }^{32}$ Rooney, p18.

${ }^{33}$ Marianne Moore, New Collected Poems, edited by Heather Cass White, New York, Farrar, Straus \& Giroux, 2017, 179; Yves Bonnefoy, On the Motion and Immobility of Douve, edited by Timothy Mathews, translated by Galway Kinnell, Hexham, Bloodaxe Books, 1992, 140/141. Octavio Paz, The Collected Poems of Octavio Paz: 1957-1987, edited and translated by Eliot Weinberger (and others), New York: New Directions, 1987, 138.

${ }^{34}$ XXXXXX, “Asbestos: The Last Modernist Object”, Modernism/Modernity Plus (forthcoming).

${ }^{35}$ Randall Jarrell, “Thoughts about Marianne Moore”, The Partisan Review, 19, 6 (1952), 687-700.

${ }^{36}$ Sabine Sielke, Fashioning the Female Subject: The Intertextual Networking of Dickinson, Moore, and Rich, Ann Arbor, University of Michigan Press, 1997, 62.

${ }^{37}$ Marianne Moore, "Marianne Moore: Poet", in Mary Austen, Everyman 's Genius, Indianapolis, The BobbsMerrill Company, 1925, 339.

${ }^{38}$ Dancy Mason, “'Another armored animal': modernist prosthesis and Marianne Moore's posthumanist animiles", Feminist Modernist Studies, 1, 3 (2018), 318-335, 320.

${ }^{39}$ Yves Bonnefoy, L'Improbable et autres essais, Paris, Gallimard, 1980, 246-7. Translations of the passage are taken from John T. Naughton, The Poetics of Yves Bonnefoy, Chicago, The University of Chicago Press, 1984, 136.

${ }^{40}$ Bonnefoy, L'Improbable, 247-8.

${ }^{41}$ Naughton, Yves Bonnefoy; Layla Roesler, “Allegory and Event: Two ways of saying the salamander in Yves Bonnefoy", Trans—, 10 (2010). Accessed 24 September 2019: http://journals.openedition.org/trans/378

${ }^{42}$ Although Galway Kinnell's translations of Bonnefoy are, in the words of Herbert Lomas, "poor" and "the inaccuracies work against, not for, effect" (71), they remain, unfortunately, the standard English version of Douve. Since my argument does not turn overly on their accuracy, I have used them as my source material. Herbert Lomas, "On the Motion and Immobility of Douve by Yves Bonnefoy, translated by Galway Kinnell”, Ambit, 132 (1993), 70-72.

${ }^{43}$ Analisa Taylor, Indigeneity in the Mexican Cultural Imagination: Thresholds of Belonging, Tucson, University of Arizona Press, 2009, 12.

${ }^{44}$ John M. Fein, Toward Octavio Paz: A Reading of His Major Poems, 1957-1976, Lexington, The University Press of Kentucky, 1986, 41.

${ }^{45}$ Fein notes that these lines “correspond precisely with a passage from [Bernardino de] Sahagún's Historia general de las cosas de Nueva España (ca. 1577)” (56). 